\begin{tabular}{c} 
JPPIPA, Vol.3 No.1 2018 \\
Jurnal Penelitian Pendidikan IPA \\
\hline
\end{tabular}

\title{
MEMBANGUN KETERAMPILAN BERPIKIR KREATIF SISWA MELALUI PEMBELAJARAN BERBASIS INKUIRI TERBIMBING
}

Oleh:

Fitri Kurniati ${ }^{1}$, Soetjipto ${ }^{2}$, Sifak Indana ${ }^{3}$

${ }^{1,2,3}$ Program Studi Pendidikan Sains, Pascasarjana, Universitas Negeri Surabaya, Indonesia

\begin{abstract}
Abstrak
Penelitian ini bertujuan untuk mendeskripsikan pengaruh pembelajaran berbasis inkuiri terbimbing terhadap keterampilan berpikir kreatif. Jenis penelitian yang digunakan adalah penelitian deskriptif kuantitatif dengan rancangan penelitian one group pretest-postest design. Sampel yang digunakan dalam penelitian ini adalah siswa kelas VIII SMP Negeri 4Lamongan, semester ganjil tahun pelajaran 2016/2017. Hasil penelitian menunjukkan: Skor rata-rata keterampilan berpikir kreatif siswa pada pre test 41,67 sedangkan post test 79, 17 dengan N-Gain 0,79 berkategori tinggi. Siswa merespon positif pembelajaran berbasis inkuiri terbimbingdengan persentase $95,79 \%$. Berdasarkan hasil penelitian, dapat disimpulkan bahwa proses pembelajaran berbasis inkuiri terbimbing dapat meningkatkan keterampilan berpikir kreatif siswa.
\end{abstract}

Kata Kunci : Inkuiri Terbimbing, Keterampilan Berpikir Kreatif

\section{Abstract}

The aim of this research is to describe the creative thinking skill and students' response to guided inquiry model.This type of research is descriptive quantitative research design with one group pretest posstest design.The samples used in the study were students of class VIII SMP Negeri 4 Lamonganin an odd semester of academic year 2016/2017. The result showed that the average score of students creative thinking skill on pre-test 41,67while post-test 79,17 and 0,79 N-Gain score. And Students gave a positive response to guided inquiry model with a percentage of $95.79 \%$. Based on the result of this recent study, guided inquiry model to facilitate creative thinking skills.

Keywords: Guided Inquiry, Creative Thinking

(C) 2018 Universitas Negeri Surabaya

\footnotetext{
Alamat Korespondensi:

Program Studi Pendidikan Sains,

Pascasarjana, Universitas Negeri Surabaya,

Surabaya 60231, Indonesia

Email: soetjipto@unesa.ac.id
} 


\section{PENDAHULUAN}

Belajar adalah proses yang berlangsung terusmenerus dan tidak dibatasi oleh ruang dan waktu, hal ini berdasar pada asumsi bahwa sepanjang kehidupan manusia akan selalu dihadapkan pada masalah atau tujuan yang ingin dicapainya. Untuk menghadapi masalah dan mencapai tujuan yang ingin dicapai, maka manusia harus belajar sepanjang hayat. Atas dasar itulah sekolah harus berperan sebagai wahana untuk memberikan latihan bagaimana cara belajar (learn how to learn).

Prinsip belajar sepanjang hayat sejalan dengan empat pilar universal seperti yang dirumuskan UNESCO (Ibrahim, 2010), yaitu belajar untuk mengetahui (learning to know), belajar dengan melakukan (learning to do), belajar menjadi diri sendiri (learning to be) dan belajar dengan bekerjasama (learning to live together) merupakan kebutuhan yang mendasar bagi setiap peserta didik. Lebih lanjut Suyono \& Hariyanto (2015) berpendapat learning to be diharapkan menjadi sasaran akhir proses pembelajaran, karena belajar untuk menjadi learning to be mengharuskan tujuan belajar dirancang dan diimplementasikan sedemikian rupa, sehingga pembelajar menjadi manusia yang utuh, yaitu manusia yang seluruh aspek kepribadiannya berkembang secara optimal dan seimbang.

Hakikat dari tujuan pendidikan menurut UNESCO di atas, tidak hanya menuntut siswa untuk tahu, tetapi juga melakukan, artinya menerapkan apa yang diketahuinya pada situasi baru, sehingga untuk tahu siswa harus melakukan dengan aktif, tidak pasif. Selain mampu bekerja secara mandiri, setiap siswa juga dituntut memiliki keterampilan sosial sehingga dapat hidup bersama dan bekerjasama dengan orang lain (Ibrahim, 2010).

Belajar pada dasarnya merupakan proses untuk membantu keterampilan berpikir (thinking skill). Keterampilan berpikir adalah salah satu aspek kecakapan hidup (life skill) yang sangat perlu mendapat perhatian dan dikembangkan melalui proses pendidikan. Kemampuan seseorang untuk dapat berhasil dalam kehidupannya terutama dalam upaya menyelesaikan masalah-masalah kehidupan yang dihadapinya ditentukan oleh berpikir yang dimilikinya. Belajar bagaimana cara berpikir yang baik menekankan pada proses mencari dan menemukan pengetahuan melaui interaksi antar siswa sebagai individu dengan lingkungan sekitar. Dalam kaitannya dengan pelajaran sains, inkuiri dan berpikir merupakan dua hal yang sangat berkaitan satu sama lain dan disarankan untuk difasilitasi perkembangannya melalui proses pembelajaran (Garrison \& Archer, 2004 dalam Jufri, 2013).
Pembelajaran IPA yang baik tidak berpusat pada guru (teacher centered), tetapi harus lebih berorientasi pada peserta didik (student centered). Peranan guru harus bergeser dari menentukan "apa yang harus dipelajari" menjadi "menyediakan dan memperkaya pengalaman belajar siswa". Pengalaman belajar diperoleh siswa melalui serangkaian kegiatan mengeksplorasi lingkungan, melalui interaksi aktif dengan teman sejawat dan seluruh lingkungan belajar di sekitarnya. Sehubungan dengan itu, pengembangan pembelajaran IPA di sekolah harus mempertimbangkan empat hal, yaitu: (1) Empat pilar pendidikan sebagaiman yang dirumuskan UNESCO; (2) Kegiatan berorientasi inkuiri dalam rangka memperoleh ilmu dan pengetahuan atas dasar rasa ingin tahu (curiosity); (3) Penyelesaian masalah dan (4) Konstruktivisme sebagai filosofi pembelajaran (Jufri, 2013).

Hakekat Kurikulum 2013 menjelaskan bahwa proses pembelajaran pada satuan pendidikan diselenggarakan secara interaktif, inspiratif, menyenangkan, menantang, memotivasi siswa untuk berpartisipasi aktif, serta memberikan ruang yang cukup bagi prakarsa, kreativitas, dan kemandirian sesuai dengan bakat, minat, dan perkembangan fisik serta psikologis siswa.

Berdasar pernyataan tersebut, maka penting untuk memberikan ruang yang cukup untuk kreatifitas siswa, termasuk dalam hal ini adalah berpikir kreatif. Dengan demikian pembelajaran harus dirancang dan dipersiapkan dengan sebaikbaiknya, dengan pembuatan perangkat pembelajaran yang sesuai dengan metode yang dilaksanakan. Perangkat pembelajaran yang dipersiapkan tentunya harus dapat memfasilitasi siswa untuk melakukan kegiatan ilmiah sesuai dengan materi yang sedang dipelajari, maka perangkat yang dimaksud adalah perangkat berbasis inkuiri terbimbing.

Melalui model inkuiri terbimbing siswa dapat menguasai konsep sains dan juga dilatih untuk meneliti suatu permasalahan dengan fakta yang ada, dimana siswa melakukan prosedur-prosedur ilmiah yang digunakan untuk mengenal masalah, mengajukan pertanyaan-pertanyaan, mengadakan prosedur-prosedur penyelidikan untuk memperoleh solusi atau jawaban. Model pembelajaran inkuiri terbimbing merupakan bagian dari pembelajaran dengan penemuan, dimana siswa didorong terlibat secara aktif untuk belajar dengan konsep-konsep dan prinsip-prinsip (Sanjaya, 2010).

Dalam pembelajaran IPA dengan model inkuiri terbimbing, guru membimbing siswa yang belum pernah mempunyai pengalaman belajar dengan kegiatan-kegiatan inkuiri. Siswa melakukan percobaan atau penyelidikan untuk menemukan konsep-konsep yang telah ditetapkan 
guru. Siswa dilibatkan secara aktif dengan mencari cara sendiri untuk mengatasi permasalahan yang sedang dihadapinya.

Penekanan utama dalam proses belajar berbasis inkuiri terbimbing, menurut Anam (2015), terletak pada kemampuan siswa untuk memahami, kemudian mengidentifikasi dengan cermat dan teliti dan diakhiri dengan memberikan jawaban atau solusi atas permasalahan yang tersaji. Oleh karena itu, metode inkuiri terbimbing sangat tepat untuk melatihkan berpikir kreatif siswa pada materi sistem pernapasan pada manusia. Sehingga diharapkan siswa tidak hanya telling science, tetapi juga doing science.

Salah satu Komperensi Dasar pembelajaran IPA SMP Kelas VIII adalah KD. 3.9 yaitu menganalisis sistem pernapasan pada manusia dan memahami gangguan pada sistem pernapasan, serta upaya menjaga kesehatan sistem pernapasan dan KD 4.9 menyajikan karya tentang upaya menjaga kesehatan sistem pernapasan. Sistem pernapasan pada manusia erat kaitannya dengan kehidupan sehari-hari. Kegiatan pembelajaran pada KD 3.9 dan 4.9 sangat memungkinkan siswa untuk mendapatkan pengalaman langsung maupun dengan melakukan percobaan, sehingga pembelajaran pada materi ini sangat sesuai jika menggunakan pembelajaran berbasis inkuirim terbimbing. Hal ini diharapakan dapat mengembangkan keterampilan berpikir siswa dengan menyajikan fenomena sains, sehingga siswa dapat memunculkan banyak ide atau alternatif dalam penyelesaian masalah yang dapat melatihkan keterampilan berpikir kreatif. Dengan keaktifan siswa dalam pembelajaran, student centered dapat dicapai dengan metode inkuiri terbimbing ini.

Hasil penelitian terhadap penerapan pembelajaran berbasis inkuiri terbimbing telah dilakukan oleh beberapa peneliti. Wibowo (2015) menyatakan perangkat pembelajaran berbasis inkuiri terbimbing dapat meningkatkan creative thinking skill dan work creatively with others. Smallhorn (2015), Sousa (2015) dan Deriina (2015) menyatakan bahwa pembelajaran inkuiri dapat meningkatkan kesempatan siswa untuk terlibat dalam kegiatan berbasis penyelidikan serta mengembangkan kemampuan menganalisis dan kemampuan berpikir. Handayani (2015) dalam penelitiannya menyatakan bahwa perangkat pembelajaran berbasis inkuiri terbimbing dapat meningkatkan aktifitas siswa dalam memberikan gagasan, inisiatif dan kerjasama. Muntaha (2013) dan Budiyanto (2014) menyatakan bahwa kemampuan berpikir kreatif dapat meningkat dengan pemberian masalah kepada siswa.

Berdasar latar belakang di atas, maka penulis tertarik untuk melakukan penelitian
"Pengembangan perangkat pembelajaran berbasis inkuiri terbimbing untuk melatihkan keterampilan berpikir kreatif siswa materi sistem pernapasan pada manusia"

\section{METODE}

Jenis penelitian ini adalah penelitian deskriptif kuantitatif. Penelitian ini ditujukan untuk mendeskripsikan ada tidaknya akibat dari suatu perlakuan yang diberikan pada subjek penelitian. Uji coba perangkat dilakukan untuk melihat kesesuaian pembelajaran dan karakteristik siswa dalam jumlah terbatas. Rancangan ini melibatkan satu kelompok yang diobservasi pada tahap pretest (O1) yang kemudian dilanjutkan dengan perlakuan tetentu (X) dan posttest (O2) (Sugiyono, 2014). Rancangan pre-experimental one group pretestposttest design dapat ditulis dengan bentuk:

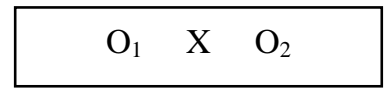

Keterangan:

$\mathrm{O}_{1}=$ pretestsebelum diberikan perlakuan

$\mathrm{X}=$ kelas dengan pembelajaran berkonteks Socio-Scientific Issues

$\mathrm{O}_{2}=$ posttest sesudah diberikan perlakuan

Kegiatan uji coba dilakukan untuk memperoleh masukan langsung dari lapangan dan penilaian keterlaksanaan perangkat pembelajaran berbasis inkuiri terbimbing

Sasaran penelitian ini diujicobakan pada 12 siswa kelas VIII di SMP Negeri 4 Lamongan semester ganjil tahun ajaran 2016/2017.

Teknik pengumpulan data yang digunakan meliputi: (1) metode observasi untuk memperoleh data keterlaksanaan pembelajaran; (2) metode tes yang digunakan untuk mengetahui perkembangan kemampuan literasi sains siswa sebelum dan sesudah pembelajaran.; (3) metode angket untuk mengetahui respon siswa setelah mengikuti proses pembelajaran.

Teknik analisis data dilakukan secara deskriptif kualitatif yaitu dengan menghitung hasil pengamatan(diamati oleh pengamat).

Analisis dari hasil angket respon siswa dianalisis secara diskriptif kuantitatif untuk mengetahui pendapat peserta didik terhadap perangkat pembelajaran yang dikembangkan.

\section{HASIL DAN PEMBAHASAN}

\section{Validasi Perangkat Pembelajaran Inkuiri Terbimbing}

Perangkat pembelajaran berbasis inkuiri terbimbing yang dikembangkan untuk melatihkan keterampilan berpikir kreatif siswa terdiri dari 
Silabus, Rencana Pelaksanaan Pembelajaran (RPP), Lembar Kegiatan Siswa (LKS), Buku Ajar Siswa (BAS) dan instrumen tes berpikir kreatif.

Perangkat pembelajaran yang telah disusun divalidasi oleh dua orang validator (dosen ahli dari Universitas Negeri Surabaya) untuk mendapatkan penilaian, saran dan masukan perbaikan sebelum perangkat tersebut diimplementasikan pada uji coba. Hasil validasi perangkat pembelajaran ditunjukkan pada Gambar 1.

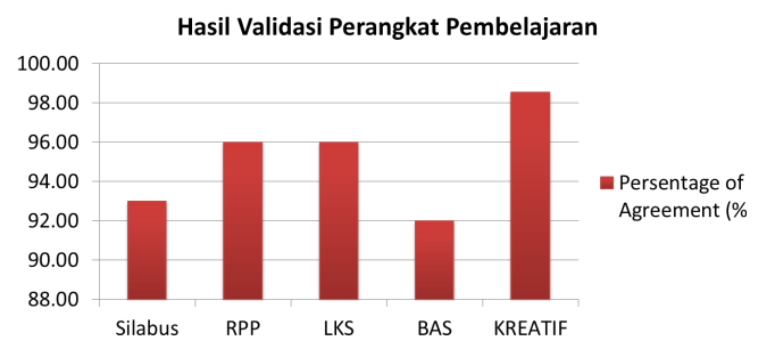

Gambar 1. Grafik Validasi Perangkat Pembelajaran

\section{Hasil Tes Keterampilan Berpikir Kreatif}

Berpikir kreatif diukur dengan menggunakan Lembar Penilaian berpikir kreatif. Penilaian diukur berdasarkan aspek-aspek berpikir kreatif siswa, yaitu: kelancaran (fluency), keluwesan (flexibility), keasliaan (originality), dan kerincian (elaboration). Hasil penilaian kemampuan berpikir kreatif siswa disajikan dalam Gambar 2.

Gambar 2 menunjukan bahwa terjadi peningkatan skor siswa dari pretest ke posttest, sekaligus peningkatan kemampuan berpikir kreatif seluruh siswa secara individual.

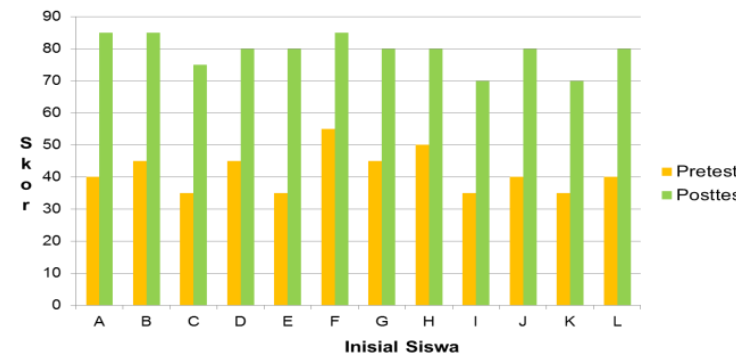

Gambar 2. Hasil Tes Keterampilan Berpikir Kreatif

Berdasarkan hasil analisis data penilaian kemampuan berpikir kreatif terjadi peningkatan skor siswa dari rata-rata pretest 41,67 dengan katagori kurang kreatif menjadi rata-rata posttest 79,17 (skala 0-100) dengan kategori kreatif (Khanafiyah, S \& Rusilowati, A. 2010), dengan $N$ Gain rata-rata sebesar 0,79 dengan kategori tinggi. Nilai gain yang termasuk dalam katagori tinggi tersebut menyatakan bahwa perangkat pembelajaran berbasis inkuiri terbimbing yang dikembangkan mampu meningkatkan keterampilan berpikir kreatif siswa.

Munandar (2014) mengemukakan ciri-ciri dari anak yang kreatif, yaitu: mereka memegang teguh pendirian dan keyakinannya sekaligus berani mengungkapkannya; memiliki rasa ingin tahu yang tinggi; mandiri dalam berfikir dan dalam memberikan pertimbangan.Model inkuiri terbimbing mengakomodir aktivitas tersebut melalui kegiatan mengidentifikasi masalah, membuat hipotesis, merancang percobaan, melakukan penyelidikan, menganalisis data, hingga pengembangan kesimpulan. Hal ini juga sejalan dengan teori skema, Piaget menyatakan bahwa pendidikan yang optimal membutuhkan pengalaman yang menantang bagi pebelajar sehingga proses asimilasi dan akomodasi dapat menghasilkan pertumbuhan intelektual (Arends, 2012). Suchman, dalam pengembangan inquiry training menyatakan bahwa, guru harus memberikan situasi yang membingungkan untuk memicu keingintahuan dan memotivasi penyelidikan (Arends, 2012; Slavin, 2011).

Skor kemampuan berpikir kreatif siswa yang tinggi dan dalam kategori kreatif setelah pembelajaran berbasis inkuiri terbimbing dikarenakan semua aspek berpikir kreatif dapat ditingkatkan oleh siswa yang meliputi: (1) Aspek Kelancaran (fluency), indikatornya adalah membuat pertanyaan sebanyak mungkin, tentunya pertanyaan harus relevan dengan topic pada bacaan yang disajikan, sehingga arus pemikiran lancar (Munandar, 2009).

Rata-rata hasil analisis keterampilan berpikir kreatif pada aspek kelancaran mengalami peningkatan dari 1,58 (skala 1-4) menjadi 3,08. (2) Aspek Keluwesan (flexibility), indikatornya adalah kemampuan menghasilkan gagasan yang bervariasi sehingga gagasan mampu mengubah cara atau metode (Munandar, 2009). Rata-rata hasil analisis keterampilan berpikir kreatif pada aspek keluwesan mengalami peningkatan dari 1,5 (skala 1-4) menjadi 3,18. (3) Aspek Keaslian (originality), dengan indikator membentuk gagasan baru, sehingga dapat memberikan jawaban yang laian dari yang lain (Munandar, 2009).

Rata-rata hasil analisis keterampilan berpikir kreatif pada aspek keaslian mengalami peningkatan dari 1,67 (skala 1-4) menjadi 3,08. (4) Aspek Elaborasi (Elaboration) dengan indikator maapu menambah atau memerinci gagasan orang laian sehingga dapat memperluas gagasan atau menguraikan detil-detil suatu gagasan (Munandar, 2009). Rata-rata hasil analisis keterampilan berpikir kreatif pada aspek elaborasi mengalami peningkatan dari 1,58 (skala 1-4) menjadi 3,42.

Berdasarkan rata-rata skor tiap aspek diatas, skor kemampuan berpikir kreatif siswa secara 
umum juga mengaalami peningkatan, dari 1, 67 menjadi 3,17 dengan kriteria tinggi.

\section{Respon Siswa}

Peningkatan keterampilan berpikir kreatif siswa siswa sangat berhubungan dan berbanding lurus dengan respon siswa terhadap proses pembelajaran yang telah dilakukan.

Pada lembar respon siswa, terdapat tujuh bagian respon siswa yang tercantum dalam angket yang harus diisi oleh siswa. Bagian pertama untuk mengetahui ketertarikan siswa terhadap komponen topik, buku LKS, model pembelajaran, cara guru mengajar, suasana belajar dan media pembelajaran yang digunakan pada saat proses pembelajaran. bagian ini 94,86\% siswa menyatakan tertarik. Bagian kedua untuk mengetahui pendapat siswa tentang kebaruan komponen pada bagian pertama dan 96,86\% siswa berpendapat baru dengan kategori kuat. bagian ketiga untuk mengetahui pendapat siswa terhadap ketertarikan tarhadap buku dan LKS. Sebanyak $94 \%$ siswa menyatakan tertarik. bagian keempat untuk mengetahui pendapat siswa tentang kebaruan terhadap LKS berbasis inkuiri terbimbing. Sebanyak 96,80\% siswa menyatakan bahwa LKS inkuiri terbimbing merupakan hal yang baru bagi mereka.

Bagian kelima untuk mengetahui respon siswa terhadap penjelasan dan bimbingan guru pada proses pembelajaran. sebanyak $100 \%$ siswa menjawab jelas dengan kategori kuat. Bagian keenam untuk mengetahui respon siswa terhadap tes yang diberikan. Sebanyak $94 \%$ siswa menjawab mudah dan bagian terakhir untuk mengetahui minat siswa terhadap pembelajaran dengan menggunakan model inkuiri terbimbing. Sebanyak $94 \%$ siswa menyatakan berminat belajar dengan model inkuiri terbimbing.

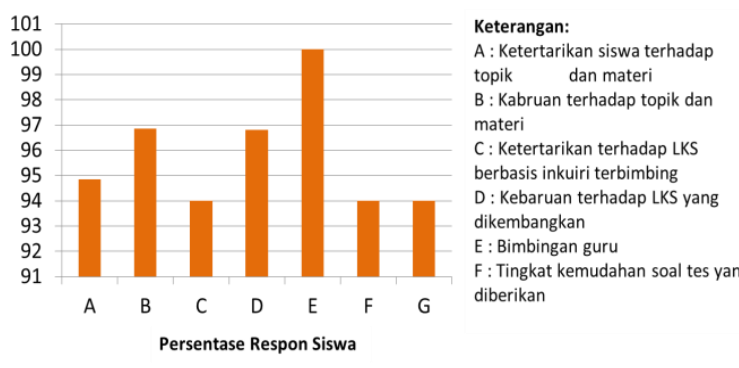

Gambar 3. Respon Siswa

Berdasar hasil analisis respon siswa terhadap pengembangan perangkat pembelajaran dan pelaksanaan pembelajaran berbasis inkuiri terbimbing didapatkan hasil bahwa sebanyak 95.79\% siswa merespon positif dengan kriteria kuat (Riduwan, 2010). Hal ini berarti siswa mendukung, merasa senang, dan berminat terhadap pembelajaran dengan menggunakan perangkat hasil pengembangan berbasis inkuiri terbimbing untuk melatihkan kemampuan berpikir kreatif siswa.

\section{PENUTUP}

\section{Simpulan}

Berdasarkan hasil analisis data penelitian dan pembahasan dapat disimpulkan sebagai berikut:

1. Skor rata-rata keterampilan berpikir kreatif siswa pada pre test 41,67 sedangkan post test 79 , literasi sains 17 dengan N-Gain 0,79 berkategori tinggi. Ini berarti pembelajaran berbasis inkuiri terbimbing dapat melatihkan keterampilan berpikir kreatif siswa.

2. Siswa merespon positif pembelajaran IPA berbasis inkuiri terbimbingdengan jumlah siswa yang merespon positif sebesar 95,79\%. Ini berarti siswa sangat berminat terhadap pembelajaran berbasis inkuiri terbimbing.

\section{Saran}

Pembelajaran untuk melatihkan keterampilan berpikir kreatif sebaiknya dilakukan melalui proses terus-menerus dan memberikan kesempatan kepada siswa untuk menemukan sendiri keterampilan tersebut, sehingga siswa terbiasa dan mandiri dalam menggali potensi keterampilan lain yang dimiliki.

\section{DAFTAR PUSTAKA}

Anam, Khoirul. 2015. Pembelajaran Berbasis Inkuiri: Metode dan Aplikasi. Yogyakarta: Pustaka Pelajar

Arends, R. 2012. Learning to teach, ninth edition. New York: Mc-Graw Hill.

Budiyanto dan Rohaeti. 2014. Pengembangan Kemampuan Berpikir Kreatif dan Kmendirian Belajar Siswa SMA Melalui Pembelajaran Berbasis Masalah. Jurnal Pengajaran Matematikan dan Ilmu Pengetahuan Alam.

Deriina. 2015. Implementation of Inquiry Training Model In Learning Physics to Improve Student Formal Thinking Ability. Jurnal Pendidikan Fisika Indonesia Vol. 2

Handayani, L., Wododo, J., Setyowati, D,. 2015. Pengembangan Perangkat Pembelajaran IPS dengan Metode Inkuiri. Journal of Educational Sical Studies.

Ibrahim, M. 2010. Pembelajaran inkuiri. Jakarta : Rhineka Cipta

Jufri, Wahab. 2013. Belajar Dan Pembelajaran Sains. Bandung: Pustaka Reka Cipta

Khanafiyah, S. \& Rusilowati, A. 2010. Penerapan Pendekatan Modified Free Inquiry Sebagai Upaya Meningkatakan Kreativitas Mahasiswa Calon Guru Dalam 
Mengembangkan Jeensi Eksperimen dan Pemahaman Terhadap Materi Fisika. Jurnal Pendidikan FMIPA Universitas Negeri Semarang

Munandar, Utami. 2009. Pengembangan Kreativitas Anak Berbakat. Jakarta: Rineka Cipta

Munandar, Utami. 2014. Pengembangan Kreativitas Anak Berbakat. Jakarta: Rineka Cipta

Munthaha dan Hartono. 2013. Pengembangan Perangkat Pembelajaran Model Problem Based Learning Untuk Meningkatkan Kemampuan Berpikir Kreatif. Journal of Primery Educational.

Sanjaya, Wina. 2010. Strategi Pembelajaran Berorientasi Standar Proses Pendidikan. Jakarta: Prenada Media Grup

Slavin. 2011. Psikologi Pendidikan: Teori dan Praktek. Jakarta: PT. Indeks
Smalhorn, M,, Young, J., 2015. Inquiry-Based Learning to Improve Student Engagement in Large First Year Topic. Journal Student Success Vol 6

Sousa. C., 2016. Inquiry Learning for Gender Equity Using History of Science in Life and Earth Sciences Learning Environment. Journal for Education, Social and Technological Science Vol. 3

Sugiyono. 2014. Metode Penelitian Kombinasi. Bandung: Alfa Beta

Suyono dan Hariyanto, 2015. Belajar dan Pembelajaran: Teori dan Konsep Dasar. Bandung: Remaja Rosdakarya

Wibowo dan Laksono.2015. Pengembangan dan Implementasi Perangkat Pembelajaran IPA Berbasis Inkuiri Terbimbing. Jurnal Inovasi Pendidikan IPA Volume 1 Nomor 2 